\title{
RE-EXAMINING \& REPOSITIONING HIGHER EDUCATION: TWENTY ECONOMIC AND DEMOGRAPHIC FACTORS DRIVING ONLINE AND BLENDED PROGRAM ENROLLMENTS
}

Kristen Betts, EdD

Kenneth Hartman, EdD

Drexel University Online

Carl Oxholm III, JD, MPP

Drexel University

\begin{abstract}
Economic and demographic shifts in the United State are transforming higher education. With substantial reductions in state funding, increasing campus energy and operational costs, endowments generating reduced returns, and a national economic readjustment of unprecedented proportions, higher education must re-examine and reposition itself to meet new and emerging challenges. This paper identifies ten economic factors and ten demographic factors that are confronting colleges and universities and driving online and blended program enrollments. While traditional face-to-face programs will always play a critical role in higher education, online and blended programs provide new opportunities to expand current student markets by offering quality programming that supports the institutional mission, increases brand recognition, and expands an institution's alumni base.
\end{abstract}

\section{KEYWORDS}

Distance Education, Online Education, Blended (Hybrid) Education, Higher Education, Economics, Demographics, Enrollment, Endowment, Recruitment, Retention

\section{INTRODUCTION}

"Severe economic pressures have created a defining moment for colleges and universities, which must fundamentally reinvent themselves to survive."

- E. Gordon Gee, Ohio State University [1]

Higher education is at a pivotal time. As with many nonprofit organizations and corporations, survival will depend upon achieving the elusive balance between flat or declining revenues and increasing expenses. As economic and demographic shifts continue to challenge higher education, and as financial constraints reset consumer preferences, institutions will have to redefine and reposition themselves as part of an increasingly competitive landscape. As Facione says, "It is time for some straight talk, starting with the realization that organizations that can't or won't adapt will fail” [2].

With severe cuts in state funding, increasing campus operational costs, reduced endowments, and a national economic crisis, the question that must be answered is: How can higher education institutions increase revenue without sacrificing or damaging the quality of programming or brand? For many 
institutions, the answer will be offering online and blended (hybrid) programs. With the increasing technological facility of students and the ubiquity of electronic communications, online and blended education provide viable and sustainable long-term options. Students have become savvy consumers who seek high quality programming across all marketed educational delivery methods including on-campus (face-to-face), blended, and online. Recognizing that competing educational programs are now just one click away, quality is critical to retention and program sustainability. Because of online and blended programming, brand recognition now goes beyond local and regional markets enabling an institution to extend its brand nationally and even globally.

Traditional, on-campus face-to-face programs will always play a critical role in higher education. However, even on-campus students will continue demanding greater access to worldwide knowledge and faster-paced, technology-supported delivery. Entirely online programs and those that blend both in-person and online features provide new opportunities to expand education beyond the limitation of the physical campus and its geographic location. Online and blended programs also provide practical education options for the millions of individuals who are currently unemployed, displaced, or dislocated, as well as those who fear losing their jobs. For these individuals, online and blended programs provide the opportunity to pursue education necessary to their future while simultaneously maintaining or seeking employment. Additionally, for Traditionalists (1927-1945) and Baby Boomers (1946-1964) who are nearing retirement but cannot afford to retire, online education and blended education provide the ideal opportunity to earn a new credential while maintaining employment or transitioning to a new career. Those in Generation X (1965-1983) and Generation Y/Millennials (1984-2002) may not enroll in traditional on-campus programs due to family (parents as well as children) and work obligations or due to the additional expense of room and board.

Online and blended programs provide opportunities to reach new student markets across all generations by expanding the accessibility of educational programs to increase an institution's future alumni base. Additionally, online and blended programs provide opportunities to re-engage and reconnect alumni through expanded programming. Therefore, colleges and universities must consider quality and scale in terms of program development, sustainability, and meeting the needs of online students [3].

\section{REVIEW OF LITERATURE}

Online education and blended education are not new to higher education. According to the National Center for Education Statistics (NCES), two-thirds (66\%) of two-year and four-year Title IV degree granting higher education institutions offer online, hybrid/blended, or other distance education courses[4]. Allen and Seaman report in Staying the Course: Online Education in the United States 2008 that online enrollment growth rates now exceed overall higher education enrollment growth rates. Between fall 2007 and fall 2008, the online enrollment growth rate increased $12 \%$ while the overall higher education enrollment growth rates increased only $1.2 \%$ [5].

In 2009, the United States Department of Education published a report entitled Evaluation of EvidenceBased Practices in Online Learning: A Meta-Analysis and Review of Online Learning Studies. This report included a meta-analysis and a systematic search for empirical studies of the effectiveness of online learning. According to the report, "The overall finding of the meta-analysis is that classes with online learning (whether taught completely online or blended) on average produce stronger student learning outcomes than do classes with solely face-to-face instruction" [6]. While the report does state that the "studies in the meta-analysis do not demonstrate that online learning is superior as a medium," it goes on to state that "online learning is much more conducive to the expansion of learning time than is face-toface instruction" [6]. With data supporting the effectiveness of online and blended education and projections for increasing growth in online and blended enrollments, it is evident that online and blended education has now become an established part of higher education. 
Re-Examining \& Repositioning Higher Education: Twenty Economic and Demographic Factors Driving Online and Blended Program Enrollments

A myriad of single factors have led to increasing online and blended enrollments, including a weak economy, growing unemployment, and fluctuating gas prices [5, 7, 8, 9, 10]. However, administrators must look beyond single factors. While single factors may contribute to increasing online and blended enrollments, it is actually the convergence of multiple factors that is transforming, and will continue to transform, the landscape of higher education.

This paper presents twenty factors - ten economic and ten demographic - that are driving online and blended enrollments. Economic factors include: (1) tuition; (2) state funding; (3) credit crisis; (4) financial aid; (5) endowments; (6) fund raising; (7) construction, maintenance, and deferred maintenance; (8) energy; (9) room and board; and (10) technology. Demographic factors include: (1) national demographic shifts; (2) population shifts; (3) diversity; (4) decreases in high school graduates in parts of the United States; (5) surges in high school graduates in parts of the United States; (6) adult learners; (7) global competition; (8) employment expectations; (9) online program inventory; and (10) market acceptance.

\section{TEN ECONOMIC FACTORS}

A description of ten key economic factors highlights the importance of single and multiple factors in relation to higher education. While some of the identified economic factors are cyclical and fluctuate, other factors will continue to increase annually. In reviewing each of the ten factors, it is important to consider how the increasing cost of each single economic factor as well the factors collectively affect institutional operating budgets and student affordability. Tuition has continued to increase annually at many institutions to cover increasing prices related to campus expenditures (such as construction, maintenance, energy, room and board, and technology). However, these escalating costs affect affordability and can affect a student's decision to enroll in either an on-campus program or an online program, particularly if the online program has fewer campus-related expenses for the student.

With decreasing state funds and reduced endowment returns, higher education institutions must closely examine all expenditures. Moreover, administrators must consider course and program options, such as online and blended delivery, that enable the institution to provide quality academic programming to an increasingly diverse student population that may be unable to physically come to campus due to professional or personal commitments. With advancements in technology, colleges and universities can readily bring the campus, including academic programs and student services, to students locally, regionally, nationally and globally.

\section{A. Tuition}

"The single most pressing public policy issue confronting American higher education in the 1990s was the affordability of a college education for individuals and for society" [11].

"An independent report (Measuring Up 2008) on American higher education flunks all but one state when it comes to affordability - an embarrassing verdict that is unlikely to improve as the economy contracts” [12].

The affordability of higher education continues to be one of the most critical policy issues in the United States. Eighteen years after Dollars, Distance, and Online Education pinpointed affordability as a national "pressing issue," affordability has become an even greater issue [11]. In 2008, the National Center for Public Policy and Higher Education published Measuring Up 2008 Report Card that "handed out Fs for affordability to 49 states, up from 43 two years ago” [12].

Today, colleges and universities are seeking innovative strategies to cut costs while keeping tuition increases to a minimum and maintaining or increasing quality. However, as noted by Alan Caniglia, 
Franklin \& Marshall College's senior associate dean of faculty and vice president of planning and institutional research, "part of rising tuition costs are due to energy costs, large purchases such as laboratory equipment for classrooms, maintaining campus buildings and grounds, and salaries” [13]. Beyond this, technology is advancing at such a pace that universities are in danger of falling quickly behind and losing status if they do not keep current. With technologically savvy students and a consumer driven society, damage to an institution's reputation can be devastating and have profound long-term effects on enrollment and retention.

For many institutions, tuition is the primary source of annual revenue and can represent up to $80 \%$ or more on the operating budget. While the term tuition dependent was once associated primarily with private institutions, shrinking tax revenues are putting more pressure on public institutions to generate more "user fees" (tuition dollars). With a weak economy and drastic cuts in state budgets across many states, even the nation's largest public institutions are now finding increased dependency on tuition. Thus, Michael Crowe, president of Arizona State University, states "Luckily, we have tuition otherwise we'd be out of business" [14].

\section{B. State Funding}

Decreases in state funding will continue to have a profound effect on higher education operating budgets. While some states are facing multi-million dollar deficits, other states are facing deficits in the billions. California is projecting a $\$ 7.5$ billion deficit in 2010-11 [15]. New York is seeking solutions for the state's estimated $\$ 6.8$ billion budget gap [16]. Ohio is expecting a $\$ 4$ to $\$ 7$ billion deficit in the state’s 2010-11 operating budget [17]. Maryland struggled to close a \$1.9 billion shortfall for the fiscal year [18]. The National Conference of State Legislatures reports that:

The latest state budget update report by the National Conference of State Legislatures paints a bleak picture for FY 2010, FY 2011 and possibly beyond. States already have closed a monumental gap of more $\$ 102$ billion for FY 2009. The outlook for FY 2010 is \$121.2 billion based on projections by 42 states and Puerto Rico [19].

A survey conducted by the Association of Governing Boards indicated that approximately $80 \%$ of the governing boards of public universities say they are dealing with state budget cuts this year and $73 \%$ of the trustees predicted state budget cuts within the year. How are college and university leaders addressing the budget shortfalls? The AGB survey revealed:

- $80 \%$ are instituting hiring freezes or restrictions;

- $\quad 48 \%$ are postponing capital spending;

- $\quad 41 \%$ are cutting budgets across-the-board;

- $\quad 22 \%$ are laying off of part-time faculty members;

- $\quad 21 \%$ are reducing academic programs; and

- $6 \%$ are setting enrollment caps [1].

Unreported were any colleges and universities that might, confidentially, be considering other financial exigencies [20].

State and college and university officials are now carefully reviewing the key provisions for higher education in the economic stimulus plan, particularly since the words "permanent cuts" are becoming increasingly visible in the press relating to higher education operating budgets. Unfortunately, history offers no examples of governmental cuts being fully restored; and once cut, state funding will increase only modestly and slowly thereafter, if at all. 
Re-Examining \& Repositioning Higher Education: Twenty Economic and

Demographic Factors Driving Online and Blended Program Enrollments

\section{Credit Crisis}

For the first time in our nation's history, Moody's Investors Services assigned on April 7, 2009 a "negative outlook" to the creditworthiness of all local governments in the United States. The net result of this special "blanket report," as reported by the New York Times will be higher cost to states, towns, and local authorities to borrow money to finance their operations, including any new capital projects (e.g., building new residence halls and athletic facilities, upgrading energy inefficient or "technology-needy" buildings, etc.) [21]. Colleges which were able to borrow money in 2007-2008 to finance capital projects are finding the tightening credit market hurting their ability to pay. Recent examples include Brandeis University which financed a new \$62-million science center and dormitory in 2007 with a variable interest rate and found its monthly payments had doubled in 2008 [9]. Georgetown University, the University of Pittsburgh Medical Center, and the University of Pennsylvania Health System have also been hit with substantially higher interest payments [9].

As a result of the credit crisis, some colleges have "quietly suspended employee-retirement contributions, frozen hiring, or as Simmons College did, cut 31 employees to reduce expenses so they could meet loan conditions set by their creditors or cover the cost of their existing debt” [22]. Likewise, the creditworthiness of parents and students is being challenged, and access to loans is restricted by banks and other lending organizations. Sallie Mae, the nation's largest student loan company, no longer provides private loans to students with below-prime credit scores and is now withholding service from colleges with poor graduation rates [23]. The bottom line is that institutions and individuals who have traditionally relied on bonds or private loans to meet their financial needs will increasingly need to identify alternative funding sources as a result of the current credit crisis and the ripples that will inevitably flow from it.

\section{Financial Aid}

The number of students seeking financial aid is increasing as the cost of tuition continues to rise across the United States:

For more than two decades, colleges and universities across the country have been jacking up tuition at a faster rate than costs have risen on any other major product or service-four times faster than the overall inflation rate and faster even than increases in the price of gasoline or health care. The result: After adjusting for financial aid, the amount families pay for college has skyrocketed 439\% since 1982 [24].

Combined with the weak economy, it is, therefore, little wonder why the US Department of Education reports an increase of $20.8 \%$ in the number of Free Applications for Federal Student Aid (FAFSA) filed in the first quarter of 2009-2010, compared to the first quarter of the 2008-2009 [25]. The US Department of Education also reported that the percentage of students taking out private loans has almost tripled over the past five years from $5 \%$ to $14 \%$ [26].

According to a 2008 study by the National Association of Student Financial Aid Administrators (NASFAA), 66\% of all undergraduates received some type of financial aid. About one-half (52\%) of all undergraduates received grant aid, and more than one-third (38\%) obtained student loans [27]. Approximately three-quarters (74\%) of all graduate students received some type of financial aid [27]. The number of individuals receiving financial aid will most likely rise due to an increase in the numbers of individuals returning to higher education. A spring 2009 survey conducted by the College Board and Art \& Science Group found that $41 \%$ of the respondents said, as a result of the tough economy, they were more seriously considering a public university or college close to home [28]. Some institutions are responding by increasing the financial aid budgets. However, the financial aid pot is only so deep, which means institutions, particularly private institutions, will likely need to draw more heavily on their endowments or substantially increase donor giving as major sources for financial aid dollars. Ursinus 
College is just one of many colleges reporting more requests for review of financial-aid needs. Rick DiFeliciantonio, vice president for enrollment at Ursinus College, stated to the Philadelphia Inquirer:

People are talking about losing 50 percent of their students' savings account [for college], or they've lost their jobs, or they're afraid of losing their jobs. All these themes we're seeing in the national news are playing themselves out in very explicit detail in these review letters we're reading. The college is trying to help families with more money. Obviously, there are limits to that," he said, asserting that about 10 to 15 percent of admitted students seemed to be struggling [29].

\section{E. Endowments}

Endowments across the country have decreased substantially and quickly, often losing as much as onethird or more of the corpus in a year's time or less. Institutions renowned for having paid their endowment managers seemingly exorbitant fees for past successes have seen their endowments experience the largest fiscal decreases. Harvard University's endowment declined from \$36.9 billion to $\$ 26$ billion in the year ending June 30, 2009 [30]. Princeton University has also seen its endowment drop considerably: "The value of the University's endowment fell 22.7 percent in the last fiscal year." [31]. Approximately $48 \%$ of Princeton's operating budget comes from its endowment; therefore, fluctuations in the endowment can profoundly affect institutional planning [31].

With more attention being paid to transparency and accountability as a result of Sarbanes-Oxley [32], trustees with fiduciary duties to the institution may be required to change investment policies, and those responsible for investing the endowments may be required to make more conservative investments. While conservatism may be prudent given recent losses, it will not only reduce earnings but also minimize, if not eliminate, the opportunity for large gains if there is a market resurgence.

Colleges and universities with endowments less than \$100 million are less dependent on investment proceeds to fund operating costs, simply because the amounts are smaller. The adverse impact can still be quite material, however, resulting in many instances in operating deficits for colleges and universities that were doing well to have break-even budgets. Deficits may violate university policy as well as prudent financial management. Since the drop in endowments will likely last several years, the gap between "what was" and "what is" has become a structural deficit for those institutions that had been dependent upon endowment proceeds to finance operations at a break-even level.

\section{F. Fund Raising}

The substantial decline in the national economy and a widespread lack of confidence in the future will continue to have a materially adverse impact on fund raising: "After years of growth and predictions that fund raising for higher education would escape the brunt of the economic crash, the recession has started to affect colleges' efforts to raise money" [33]. Major gifts have been the hardest hit as large gifts may be linked to the stock market where donors may have lost significant wealth as a result of the recession [33]. Declines in market value of personal investments may cause donors to postpone making gifts because they might feel the need to maintain assets for personal use, or simply because the value of the gift has materially declined with the corresponding tax deduction. As discretionary income has been reduced, so have contributions to annual fund solicitations. Many institutions have had to extend, suspend, or defer capital campaigns, some having staffed up in anticipation for donations that now are unlikely to come. Even those institutions that have experienced increases in giving have done so for specific reasons (e.g., to preserve need-blind admissions or to fund scholarships), rendering the funds "restricted" and not available for general institutional operations. 
Re-Examining \& Repositioning Higher Education: Twenty Economic and

Demographic Factors Driving Online and Blended Program Enrollments

Decreases in fund raising (and failures to achieve planned increases) across the nation have led to development offices to re-examine the way in which they operate. As indicated by in the article "Making Tough Choices in the Fund-Raising Office," "Administrators need to take a tough look at their operations and decide what is essential to fulfill the primary mission of the institution" [34]. Additionally, as indicated in an Eduventures survey of 48 colleges, the recession has led many fund-raising operations to cut costs, including eliminating nonessential travel (63\%); freezing hiring or not filling vacant positions (58\%); canceling/scaling back events (56\%); reducing print publications (52\%); layoffs (13\%); and combining departments or positions (13\%) [35]. Only 8\% of the intuitions surveyed reported no changes at all. As development officers continue to build long-term relationships with donors, "it's all hands on deck," says Edith H. Falk, chief executive of Campbell \& Company, as the nation moves through the recession to a stronger economy [33].

\section{G. Construction, Maintenance and Deferred Maintenance}

"Space is a serious, expensive business on college campuses. There is a saying: Academics will fight over money and kill over space” [36].

Costs relating to campus expansion, maintenance, and deferred maintenance have increased significantly over the past five years. For colleges and universities, Carlson [36] indicates that "facilities are second only to personnel in campus expenditures" and "maintenance, utilities, and renewal costs can compose about 70 percent of the lifetime costs of a building." These costs were substantially increasing even before the demand for sustainability and reduction in greenhouse gasses put new capital projects on institutions' must-do lists.

According to Ken Simonson, chief economist for the Associated General Contractors of America (AGC), "Surging prices for diesel fuel, asphalt, steel, and other materials are clobbering construction budgets" [37]. Construction costs including materials like aluminum have set record highs while natural gas doubled in price from 2007. These increases have triggered spikes in the cost of construction plastics (e.g., polyvinyl chloride pipe, insulation, etc.) and petroleum-based products (e.g., asphalt, roofing shingles, flooring materials, etc.) [37]. Construction increases also include concrete. Simonson predicts "Overall, construction materials prices will jump about 7\% a year for the next several years" [37]. Furthermore, Simonson notes that worldwide demand from countries such as China and India will continue to keep up costs pressure on construction materials.

Maintenance and deferred maintenance are closely linked to the cost of construction materials and inflation. In Ohio, public universities and colleges now face a multibillion-dollar backlog of construction needs [38]. According to the Ohio Board of Regents, "close to half of all educationally-related buildings (in Ohio) were built between 1965 and 1985. It is that large block of buildings ... that now need major renovation and maintenance" [38]. The simultaneous aging of the buildings is referred to as "block obsolescence" by the Ohio Regents. The cost for rehabbing or rebuilding for the estimated 37.2 million square feet of education-related space is $\$ 3.9$ billion to $\$ 5$ billion [38]. Deferred in the past and now demanding action, these capital projects will pull budget dollars from other university priorities.

\section{H. Energy}

The Energy Information Administration (EIA) provides official energy statistics from the U.S. Government and Department of Energy. The EIA lists energy sources as including petroleum (e.g., crude oil, gasoline, heating oil, diesel, petroleum products, etc.), natural gas, electricity, coal, renewable and alternative fuels (e.g., hydropower, solar, biomass, ethanol, etc.), and nuclear. Few college and university campuses generate a portion, much less a majority, of their own power; therefore, fluctuations in energy costs can greatly impact institutional budgets. Reduced energy supplies and increased demand, as from countries becoming increasingly industrialized, are not the only sources of rising prices. Impending utility 
deregulation and the proposed tax on carbon will also force prices to catapult. Roger Bruszewski, vice president for finance and administration at Millersville University (MU) has stated the deregulation of utility companies will increase MU's expenses. According to Bruszewski "the college is projecting that MU’s energy bills will increase from \$2 million to \$3 million [due to deregulation]. That could contribute to even higher tuition bills" [13].

Energy prices have fluctuated greatly, particularly gasoline. The cost of gasoline went as high as $\$ 4.11$ in July 2008 to as low as \$1.66 in December 2008 and then up to \$2.64 in November 2009 [39]. Higher education institutions, students, faculty (full-time and part-time), and staff are greatly affected by these fluctuating costs. Energy use has become a matter of investment strategy, as institutions decide whether to commit to volume purchases in advance to fix the price. Articles during summer 2008 highlight the impact that energy costs can have on higher education: "High Gas Prices Hit Campus Hard" [8], "\$4-aGallon Gas Drives More Students to Online Courses" [40], and "Price of Fuels Tough Choices for Adjuncts" [41]. Academia has seen this before, as these titles are similar to 2006 articles: "Fluctuating Gas Prices Brake Students Who Commute" [42] and "High Gas Prices Taking Toll on Student Drivers" [43]. Costs of gasoline as well as other energy sources will continue to fluctuate. Therefore, higher education leaders need to closely examine how energy-related costs affect campuses, students, faculty, and staff so they can develop strategies or programming that best maximizes expenditures on behalf of all stakeholders.

\section{Room and Board}

Room and board is typically the second largest component of educational costs. Across the United States, colleges and universities have varying room and board (residency) requirements. While some institutions may require all freshmen to live on campus other institutions may have a four-year residency requirement where students must live on campus from matriculation until graduation. Costs related to room and board also vary from one campus to another. However, "room and board and other living costs have increased faster than inflation over time, and for most students, grant aid doesn't stretch far enough to cover these expenses" [44]. Rising costs can be attributed to the increasing costs that institutions incur as a result of previously discussed economic factors such as maintenance, deferred maintenance, construction, and energy. For the 2009-2010 school year, room and board increased 5.4\% at public colleges and $4.2 \%$ at private colleges to an average price of $\$ 8,193$ and $\$ 9,363$, respectively” [45].

Food prices, much like energy costs, can fluctuate greatly and affect higher education institutions. In 2008, retail food prices jumped 6\% which is triple the normal rate of inflation. "Food prices tend to go up pretty quickly and they tend to stick on the way down" according to Jim Sartwelle, an economist with the American Farm Bureau [46]. Increases in food prices affect college and university dining services and tuition. As a result, many dining halls are reducing portions as well as eliminating popular dishes to try and offset projected deficits due to rising food costs [46]. As indicated by Hermes [46] "Because mealplan prices are usually set once a year, dining operations have been absorbing any excessive price increases, which can surpass hundreds of thousands of dollars at larger institutions.” To help offset food service costs, colleges and universities are trying to be creative with menu options, renegotiating contracts with food suppliers, and "shelving the trays in hopes of conserving water, cutting food waste, softening the ambience and saving money” [46, 47].

Recognizing that affordability is often a key factor when students are selecting a college or university, it is important that administrators examine, identify, and implement all cost saving sustainable strategies that affect the enrollment price tag. The cumulative cost of tuition, room and board coupled with fees, books, and supplies continues to increase on an annual basis. According to the College Board, "This year the average total charges for tuition, fees, room and board are \$14,333 for in-state students, \$25,200 out of state. The average total at private campuses is $\$ 34,132$ ” [48]. With increasing numbers of non- 
Re-Examining \& Repositioning Higher Education: Twenty Economic and

Demographic Factors Driving Online and Blended Program Enrollments

traditional students seeking degree programs, at what point does affordability drive students to seek online or blended programs that do not include traditional residency-related costs, particularly if they can graduate with the same degree?

\section{J. Technology}

The results of the 2008 Current Issues Survey, administered annually since 2003 by EDUCAUSE, reveal that the top-three issues in terms of strategic importance to institutions are (1) Security, (2) Administrative/Enterprise Resource Planning (ERP)/Information Systems, and (3) Funding Information Technology (IT) [49]. Funding IT was ranked the number one issue for three straight years, 2003-2005, until 2006 when Security and Identity Management emerged as number one. In 2007, IT Funding moved back to the top spot, with Security as number two. In 2008, Security was number one. With both Security and IT Funding, the common element is cost, and insufficient budgetary allocations threaten an institution's strategic infrastructure. The 2007 Survey of Technology Spending, conducted annually by the Professional Media Group LLC, found that 51\% of all respondents reported an increase in IT budgets [50]. More and more students are expecting a wireless campus environment, multimedia classrooms, web enhanced courses, optional online courses, electronic resources, access to the library's digital collection and administrative records, and 24/7 tech support. Therefore, it is imperative that institutions stay current with the purchase and deployment of technology from administrative, student, and instructional perspectives.

\section{TEN DEMOGRAPHIC FACTORS}

Demographics have always had profound effects on higher education, and the impending shifts will undoubtedly change higher education in many significant ways. There are ten factors that must be proactively addressed if a college or university is to remain competitive and sustainable. In reviewing each of the ten factors, it is important to consider how population shifts both on national and state levels will affect higher education. In states with decreasing populations and decreasing high school graduates, competition within states for students will increasingly force colleges and universities to reach out to attract students. In states with surging populations, higher education administrators must develop strategies to optimize the campus infrastructure to meet the needs of increasing high school graduates. However, in both cases, competition for state funding will continue to increase as a result of population decreases and increases.

The demand for higher education degrees by employers is greater today than ever. As indicated by Spellings [51], an undergraduate degree is now considered a prerequisite in many fields, with advanced degrees preferred for entry-level employment. For the increasing non-traditional student population, online and blended education have become viable options, particularly for those who are (a) working fulltime, (b) unemployed and seeking employment, (c) displaced or dislocated, (d) have family responsibilities, or (e) are unable to afford additional costs related to enrollment in traditional residential campuses. With increasing online degree acceptance by employers and a growing national inventory of online courses and programs, online and blended education are now a part of the higher education landscape.

\section{A. National Demographic Shifts}

The United States will experience shifts in national demographics over the next twenty-five to forty years. It is projected that the US population will rise from 296 million in 2005 to 438 million in 2050 with 82\% of this increase representing immigrants arriving during this time as well as their US born descendents [52].

Currently, 34\% of the US population is minority. According to the US Census Bureau, the US population 
will increase to $54 \%$ minority by 2050 with the term minority as defined by the US Census Bureau as anyone who indicated that they were either Hispanic or a race other than white alone [53]. By 2050, 62\% of the nation's children will be minority, with almost two thirds of them Hispanic [53]. The challenges presented by immigrants are multiplied when they are undocumented, because for them, as the National Conference for States Legislatures noted, there is no federal financing:

Since 2001, more than 20 states have introduced bills addressing in-state tuition for undocumented immigrants. Seven states have established new residency standards allowing unauthorized immigrant students to receive in-state tuition under certain conditions. Students without legal immigrant status continue to be ineligible for federal financial aid, although states are required to provide K-12 public education as a result of a 1982 Supreme Court decision [54].

As the US population continues to grow, there is a projected decline in the percentage of the population in the working ages. The US Census Bureau projects that the population between eighteen and sixty-four years old will decrease from 63\% in 2008 to 57\% in 2050. Projections also indicate that as the minority population grows, over half (55\%) of the working-age population will be minority by 2050 [53].

Projected demographic shifts will require that resources be devoted to addressing cultural differences as well as the gap in language skills. With already strapped budgets, states will be challenged in terms of annual resource allocation, increasing competition for higher education funding.

\section{B. Population Shifts}

Florida, California, and Texas will sustain the largest population growth between 2000 and 2030. According to the US Census Bureau, these three states will account for approximately half of the United States population growth between 2000 and 2030 [55]. Projections by the US Census Bureau indicate that the "top five fastest-growing states between 2000 and 2030 will be Nevada (114\%), Arizona (109\%), Florida (80\%), Texas (60\%), and Utah (56\%)” [55].

While many states will see increases in population growth, other states will see minimal increases and even decreases. For example, there are five states that will see less than a $6 \%$ increase in population growth by 2015, including Wyoming (+5.9\%), Pennsylvania (+4.0\%), New York (+2.6\%), Ohio (+1.7\%), and Iowa (+1.0\%). Two states will actually see decreases in population growth: West Virginia (-4.9\%) and North Dakota (-5.5\%) [55]. Of these seven states, four are projected to have more people sixty-five and older than under eighteen by 2030 (Wyoming, Pennsylvania, West Virginia, and North Dakota) [55].

As state populations increase and decrease, there will be increasing fiscal competition for state funding. In states with increasing populations, there will be increased demand on state funding for healthcare, social security, and education. For states with decreasing populations, the smaller tax base will influence overall funding that affects K-12 and higher education systems.

\section{Diversity}

As previously indicated, the US Census Bureau projects the US population to be $54 \%$ minority by 2050 [52]. For many states, there will be extensive population growth ranging between $50 \%$ to over $100 \%$ with a large percentage representing minority population growth [52]. In a 2008 report entitled Knocking at the College Door, the Western Interstate Commission for Higher Education (WICHE) examines race/ethnicity and educational attainment. In the forward of the report, WICHE President David Longanecker writes:

Gaps in educational attainment based on race/ethnicity - gaps that translate into huge differences in individual opportunity - have long existed, and eliminating these gaps has been the target of many public policy efforts. Such efforts generally have sought first and foremost to assure an 
Re-Examining \& Repositioning Higher Education: Twenty Economic and

Demographic Factors Driving Online and Blended Program Enrollments

equal playing field for all students, one in which hard work and ingenuity determine success. Certainly, providing for equal educational opportunity for all individuals is as vital as ever and the right thing to do morally. Today, however, we have a second, equally critical motivation to "do the right thing": our nation's future prosperity and security depend on it. The urgency of reducing educational attainment gaps is intensifying, due to the changing demographics of our student population. Failure to more fully address the educational needs of our rapidly growing minority populations threatens our nation's future [56].

According to Longanecker, higher education leaders must work collaboratively to address gaps in educational attainment based on race/ethnicity in the United States that translate into increased individual opportunity. It is imperative that leaders identify ways to provide equal educational opportunities for all individuals, particularly since minorities will represent $62 \%$ of the nation's population of children and $55 \%$ of the working-age population by 2050 [53].

Projections indicate that some states will experience much larger population growth, particularly minority growth, than other states. However, as indicated by Longanecker, addressing gaps in educational attainment based on race/ethnicity is a national issue. It is also an issue that affects resource allocations for K-12 and higher education.

\section{Decreases in High School Graduates in Parts of the United States}

The number of high school graduates nationwide is expected to have peaked in 2008 at 3.34 million and then to decline until 2015 [57], after which it will begin to grow again. By 2015, 54\% of states will face decreasing numbers of high school graduates, greatly impacting enrollment in higher education. Knocking at the College Door indicates that many Midwestern and Northeastern states will see the total number of high school graduates decrease by $10 \%$ or more by 2015 [56]. According to the 2008 Chronicle of Higher Education Almanac, states expecting some of the largest decreases include Vermont (-23\%) and North Dakota (-18\%) [58].

For states expecting decreases in the number of high school graduates, competition between in-state colleges and universities will increase as institutions vie to enroll and retain eligible students. Therefore, higher education institutions within these states will need to develop innovative enrollment strategies to reach new student markets including online and blended program delivery options.

\section{E. Surges in High School Graduates in Parts of the United States}

National demographic shifts will greatly challenge some states to meet the extensive population growth and significant increases in the number of high school graduates. According to the 2008 Chronicle of Higher Education Almanac, states that will be leading growth in the number of high school graduates between 2008-09 to 2018-19 include Nevada (+33\%), Arizona (+29\%), Utah (+20\%), Idaho (+20\%), Georgia (+20\%), and Texas (+19\%) [58]. These numbers will put increasing pressure on states to provide adequate educational opportunity for their residents.

California is a prime example of a state in which there have been large increases in the number of qualified students who are eligible to enroll in higher education, but there are limited slots for enrollment. "Between 2003 and 2007, the number of public high school seniors eligible for the University of California or California State University [the two state-funded systems of higher education] increased by $11 \%$ " [59]. However, both of these systems have announced plans to "to cut their budgets and shrink enrollments in the face of reduced state funding" [59]. As revealed in the December 2008 article "More Eligible Students, Fewer College Slots," although California high schools are graduating more students who are qualified and eligible to enroll in a public university system than in past years, particularly Latinos, not all students will have the opportunity to enroll [59]. "The message to the universities is that they can no longer accommodate growth by building new campuses and increasing financial aid” [59]. 
Like California, many other states will be challenged by increasing numbers of eligible students and limited college slots. Therefore, higher education leaders need to consider the development of educational delivery options, such as online and blended, that enable colleges and universities to accommodate the growing, qualified student population while keeping costs at a minimum.

\section{F. Adult Learners}

In 2005, James Gorman, president of the Global Private Client Group of Merrill Lynch, stated "Baby boomers fundamentally will reinvent retirement, and this has profound implications for how we at Merrill Lynch need to advise this generation of clients - individuals as well as retirement plan sponsors” [60]. The 2006 Merrill Lynch New Retirement Study revealed 71\% of Americans between the ages of 25 and 70 hopes to continue working past the expected retirement age and not necessarily in the same line of work [60]. In fact, the study indicated that over half of those between 51 and 70 years old were already taking steps to prepare for a new career by talking to others, attending classes or researching opportunities.

In 2007, the American Council for Education (ACE) published Framing New Terrain: Older Adults and Higher Education. This report further substantiated Gorman's notion of reinventing retirement. According to Framing New Terrain,

As the population of older adults not only expands, but also changes, so does the language used to describe it. Retirees and seniors are now rebounders, prime timers, or recareerers. In short, the term retirement is being retired, or at least redefined. Instead, increasing numbers of adults aged 55 to 79 are entering the third age of life-a stage in recent years defined by personal achievement and learning for self-development—with new plans for their later years in mind [61].

As highlighted in the ACE report, there are extensive current and future opportunities for colleges and universities to expand their outreach to this population through online and blended education.

In an interview with the GreenTree Gazette, Craig McGuinn discusses with how Ward Media is reaching out to the adult higher education market. McGuinn identifies three key segments in today's adult higher education market:

(1) Adults who need a trade or specific occupational skill to insure employability or make a career shift. (2) Working adults who believe their long-term career or pension opportunities will be enhanced by an Associate or Bachelors degree. (3) Bachelor degree holders who want a higher degree that can be obtained while employed full-time [62].

\section{G. Global Competition}

There are few things as fundamental to the American Dream or as essential for America's success as a good education. This has never been more true than it is today. At a time when our children are competing with kids in China and India, the best job qualification you can have is a college degree or advanced training. If you do have that kind of education, then you're well prepared for the future because half of the fastest growing jobs in America require a Bachelor's degree or more. And if you don't have a college degree, you're more than twice as likely to be unemployed as somebody who does. So the stakes could not be higher for young people [63]. $\sim$ President Barak Obama 
Re-Examining \& Repositioning Higher Education: Twenty Economic and

Demographic Factors Driving Online and Blended Program Enrollments

By ensuring that higher education is affordable and accessible for all our young people, we will make certain that our nation is prepared to compete in an information-age economy [64]. US Secretary of Education, Arne Duncan

President Obama has clearly articulated the need for a higher education degree. His administration, while still in its first year, has submitted an unprecedented number of proposals to reshape and redirect Title IV funding, as well as a willingness to use the US tax code to help certain individuals and families pay for college. As indicated by Cavanaugh,

The recent debate over the inclusion of colleges in the stimulus package put two aspects of higher education in the spotlight: the importance of attending college, and the role of higher education as an enormous economic driver. Affordability and accessibility to higher education are critical in making "certain that our nation is prepared to compete in an information-age economy" [65].

However, as revealed in Global Higher Education Rankings, while the United States ranks fourth for accessibility to higher education when compared globally to 13 countries, it ranks thirteenth for affordability when compared to 15 countries [66].

According to the US Census Bureau, just 29\% of adults twenty-five and older in the United States have a bachelor's degree or higher and $87 \%$ has completed high school [64]. Research indicates several benefits related to earning a bachelor's degree. For example, the US Census Bureau reported in 2009 that workers with a high school degree earned an average of \$31,286 in 2007 and workers with a bachelor's degree earned an average of \$57,181 [67]. Moreover, the US Department of Labor reports "the unemployment rate for workers who dropped out of high school is nearly four times the rate for college graduates” [67]. Additionally, the College Board reports in Education Pays: The Benefits of Higher Education for Individuals and Society "a positive correlation between higher levels of education and higher earnings for all racial/ethnic groups and for both men and women” [68]. In addition to higher earnings, the College Board states that college graduates are more likely to have employer-provided health insurance and pension benefits, better health, greater opportunities for the next generation, and higher levels of civic participation [68]. Therefore, administrators need to consider delivery methods that extend educational opportunities beyond the campus to the larger population.

\section{H. Employment Expectations}

"The labor market demands greater skills than ever before as a precondition for higher earnings," according to Hozler [69]. In fact, increasing numbers of professions are requiring some level of postsecondary education. The Career Voyage website developed by the US Departments of Labor and Education reveals that the top fifty in-demand occupations require a college degree [70]. With increasing unemployment rates over the past year, competition for jobs has also increased putting more demand on the need for a higher education degree.

With advances in technology and telecommunications, the labor market will continue to need employees with skills and knowledge to lead innovation. As the nation continues to struggle globally in a weak economy, it will be the US workforce that leads the country toward sustainability. President Barak Obama has clearly articulated to the nation the need for higher education [63]. Therefore, it is imperative that government, corporate, higher education, and civic leaders work collaboratively to identify strategies to provide higher education opportunities through cost-effective and quality programming that will enable the nation to again lead on a global front and provide increased professional and personal benefits to workers [68]. 


\section{Increasing Online Inventory}

The exact number of colleges and universities in the United States that offer online education degrees is difficult to determine because new online programs are launched on an ongoing basis. According to Newsweek Showcase, "The sheer number of distance learning and online degrees available is enormous and is growing daily. Similarly the number of schools and institutions that offer learning online is also expanding rapidly” [71].

Over the past two decades, online education has transitioned from an emerging sector to a multi-billion dollar market [72]. According to MediaTech Publishing, eLearning is predicted to exceed \$52.6 billion dollars worldwide [73]. As stated in a press release showcasing National Distance Learning Week, an initiative by the United States Distance Learning Association (USDLA):

Distance learning is a multi-billion dollar enterprise and the fastest growing segment of the education market. Commercial and government markets around the world recognize how distance learning, education and training makes a strategic contribution to achieving organizational performance objectives, leveraging talent and resources, and implementing and preserving institutional knowledge [74].

The state of Minnesota is taking a very proactive position with online education and expanding its educational outreach through its public colleges and universities. In November 2008, the Governor of Minnesota and the Chairman of the Minnesota State Colleges and Universities (MnSCU) Board of Trustees Chair announced a goal to have $25 \%$ of all MnSCU credits earned through online courses by 2015 [75]. With Minnesota expecting a 2\% decrease in the number of high school graduates between 2008-09 and 2018-19 as well as statewide budget cuts, online education is providing alternative educational delivery methods to reach extended student populations.

It is clear that through the proliferation of online programs that online education is now a part of the higher education landscape. As other states begin to face similar challenges as Minnesota, college and university systems may also begin migrating courses or programs to become part of their online inventory as a viable, sustainable, and cost-effective option for increasing and decreasing state populations.

\section{J. Online Degree Acceptance}

Since 2001, higher education institutions have experienced amazing growth in the number of college students taking online courses. According to the Sloan Consortium:

- almost 3.9 million students were talking at least one online course during the fall 2007 fall term (a $12 \%$ increase over the number reported the previous year);

- the $12.9 \%$ growth rate for online enrollments between fall 2006 and fall 2007 far exceeded the $1.2 \%$ growth of the overall higher education student population; and

- over $20 \%$ of all US higher education students were taking at least one online course in the fall of 2007 [5].

The high acceptance rate of online degree programs in higher education as indicated by the extensive growth reported by the Sloan Consortium should come as no surprise to educators. Today's students, often referred to as the Millennial Generation, have been raised in a digital environment, where so-called smartphones, laptop computers, and high speed-wireless Internet access are a normal part of their daily lives.

The United States military has been one of the greatest leaders in distance education. According to the Journal of Higher Learning for Today’s Servicemember, 
Re-Examining \& Repositioning Higher Education: Twenty Economic and

Demographic Factors Driving Online and Blended Program Enrollments

Since the mid-1970s, the number of servicemembers taking online college courses has increased from 5 percent to more than 70 percent last year. Currently, more than two-thirds of the military's tuition assistance funding is used for distance learning courses [76].

In August 2009, the new GI Bill (called the "Post 9/11” GI Bill or Chapter 33 GI Bill) began providing millions of military personnel (veterans, active duty, reserves, National Guard) the opportunity to attend college at little to no cost [77]. While national data is not currently available, it will be interesting to follow future enrollment trends highlighting the types of educational programs with delivery options for which military personnel enroll. Information regarding the educational benefits of the GI Bill is available through the United States Department of Veterans Affairs' website at http://www.gibill.va.gov/GI_Bill_Info/benefits.htm [77].

\section{IMPLICATIONS OF ECONOMIC AND DEMOGRAPHIC FACTORS}

American higher education has clearly reached another crossroads in its development, but one unlike anything else it has faced in its nearly four hundred-year history. Never before have so many factors come together simultaneously to challenge how education is delivered. At the same time, the vicissitudes of the economy have caused the demands of the technological revolution to collide with financial shortages. The identified twenty economic and demographic factors are clearly not the only places where costs are rising beyond the control of colleges and universities. However, each factor directly or indirectly affects costs and affordability, consequently influencing educational delivery and enrollment.

An additional factor to be considered is the cost of employee benefits, particularly healthcare. The results of a 2009 employee health-care benefits survey conducted by the College and University Professional Association for Human Resources revealed that "the total cost of the plans' premiums grew 3.7 percent for employee-only coverage and 5.7 percent for employee-and -family coverage” [78] The results further revealed that the increases over the past two years amounted to about $11 \%$ and $14 \%$, with institutions absorbing most of the increase [78]. Factors such as healthcare may become more of an economic issue in higher education with new government policies and an aging faculty population. This leads to a poignant question: Will increasing costs related to employee benefits lead to increased development of online and blended programs as administrators seek strategies to decrease instructional expenditures by hiring parttime faculty with fewer benefits?

Institutions of higher education must be able to provide education to more students in the same (limited) amount of space. Building new buildings and renovating existing ones are options that economic factors will continue to make less likely. Education must also be accessible to people of increasing diversity whose lives have become significantly more complicated because of work and family demands, and for whom the costs of transportation to and from campus will be of increasing concern. Information is no longer defined by what is in the university library (or through inter-library loan), but what is "accessible virtually and instantaneously" over the internet by students who have been using technology most of their lives.

Any one, two or even three of the twenty identified factors could probably be handled by tightening belts and deferring some "wants" in favor of "needs." Taken together, however, these factors make reexamination and repositioning imperative. These economic and demographic factors are changing the landscape of higher education and driving current and future online and blended program enrollments.

Times have changed and higher education institutions must change with them. The push-and-pull of economic and demographic forces require that colleges and universities integrate and utilize technology 
as much as possible while maintaining academic excellence and concurrently freeing up physical space, expanding the number of students, and teaching in ways that current learners are accustomed to learning.

\section{CONCLUSIONS}

Why should colleges and universities of all sizes, both two-year and four-year, public as well as private, consider offering or increasing online and blended courses and degree programs?

Higher education will continue to provide hope and new opportunities for those seeking careers, and reentry into the employment market. Today, online and blended education are an integral part of higher education. Through balancing academic quality and accountability with flexible scheduling, online and blended education provide long-term sustainable programming opportunities for colleges and universities. Online and blended programs also enable institutions to expand student markets nationally and internationally, moving beyond traditional local, regional and state markets. These expanded student markets provide opportunities for new institutional revenue and the expanding of an institution's alumni base.

In "A Straight-Talk Survival Guide for Colleges," Facione shares two messages with higher education institutions: (1) "competition is going to become fierce;" and (2) "there will be casualties, just as commercial businesses will fail and other worthy nonprofit organizations will go broke” [2]. For institutions that are not proactively exploring new student markets or new programming options, financial crisis or exigency may come as an unplanned reality. Face-to-face courses and programs will always play a critical role in higher education in the United States. However, economic and demographic factors are requiring higher education institutions to re-examine and reposition themselves. These factors will continue to drive current and future online and blended program enrollments.

\section{ABOUT THE AUTHORS}

Dr. Kristen Betts is an associate clinical professor in the School of Education's Higher Education Program at Drexel University. Dr. Betts' expertise is online and blended education with a research focus on the recruitment, engagement, and retention of students and faculty. Dr. Betts served as the founding director of the Master of Science in Higher Education (MSHE) Program at Drexel University. In April 2008, the MSHE Program received the Best Practices Award in Distance Learning Programming from the United States Distance Learning Association (USDLA). In 2009, Dr. Betts was named as one of Drexel University's award recipients for Outstanding Online Instructor. Dr. Betts publishes and presents nationally and internationally on online and blended education, online human touch, communication, learning simulation, cooperative education/work integrated learning, community development, multigenerational learning, program sustainability, branding, and faculty training and development. Drexel University: http://www.drexel.edu/.

Dr. Kenneth Hartman is currently the academic director of Drexel University Online at Drexel University, as well as adjunct professor in School of Education at Drexel University. Recent awards include: the 2006 Pennsylvania Association for College Admission Counseling Partner in Education Award, and Drexel University's School of Education 2006 Faculty Fellow and Associate Award, the 2007 Educator of the Year by The University of Pennsylvania, and the 2008 Leadership in Distance Learning Program Administration Award from the United States Distance Learning Association. Drexel University Online: http://www.drexel.com/.

Carl Oxholm III, JD, MPP, senior vice president of Drexel University, is currently leading the establishment of Drexel's new graduate campus in Sacramento, California, where one doctorate and eight master's degree programs offered by five colleges are being taught in a blended format, leveraging the state-of-art technology to link students on the west coast with faculty and experts not only in Philadelphia 
Re-Examining \& Repositioning Higher Education: Twenty Economic and Demographic Factors Driving Online and Blended Program Enrollments

but around the world. Drexel University-Center for Graduate Studies, Sacramento, California: http://sacramento.drexel.edu/.

\section{REFERENCES}

1. Fain, P. “Trustee survey paints grim budget picture over next year for public universities" in The Chronicle of Higher Education 55(34): A13, March 31, 2009. Available: http://chronicle .com/weekly/v55/i34/34a01301.htm.

2. Facione, P. "A straight-talk survival guide for colleges" in The Chronicle of Higher Education 55(28): A36, Mar, 20, 2009. Available: http://chronicle.com/free/v55/i28/28a03601.htm.

3. Hartman, K. and K. Betts. "Quality and scaling: Oxymoron or reality in online degrees at non-profit colleges and universities” in Magna Publications 13(10): cover-2, Distance Education Report, May 15, 2009. Available: http://www.magnapubs.com/issues/magnapubs der/13 10/news/602493-1.html.

4. National Center for Education Statistics. Distance education at degree granting postsecondary institutions: 2006-07, Washington, DC: US Department of Education, 2008.

5. Allen, I. E. \& J. Seaman. Staying the course: Online education in the United States 2008, The Sloan Consortium, Babson Survey Research Group, 2008. Available: http://www.sloanconsortium.org /publications/survey/pdf/staying_the_course.pdf.

6. United States Department of Education. Evaluation of evidence-based practices in online learning: A meta-analysis and review of online learning studies. U.S. Department of Education, Office of Planning, Evaluation, and Policy Development, Washington, DC. 2009.

7. Bureau of Labor Statistics. "The employment situation-September 2009," United States Department of Labor, 2009. Available: http://www.bls.gov/news.release/empsit.nr0.htm.

8. McClure, A. "High gas prices hit campus hard” in University Business 12(9): 12, 2008.

9. Basken, P. "After lurking for months, credit crisis begins Biting at higher education" in The Chronicle of Higher Education, Feb. 1, 2009. Available: http://chronicle.com/weekly/v54/i25 /25a02201.htm.

10. Kelsey, N. "High gas prices fuel boom in online classes" in Boston.com, 2008. Available: http://www.boston.com/news/education/higher/articles/2008/07/09/high_gas_prices_fuel_boom_in_o nline_classes.

11. Munitz, B. "Foreword" in Dollars, distance, and online education: The new economics of college teaching and learning, American Council on Education, Oryx Press, Phoenix Arizona, 2000.

12. Pope, J. "Illinois flunks college affordability study" in the Huffington Post, Dec. 3, 2008. Available: http://www.huffingtonpost.com/2008/12/03/illinois-flunks-college-a_n_148074.html.

13. Pennino, M. "Colleges cope with rising energy costs” in Lancaster Online.com, July 26, 2009. Available: http://www.universitybusiness.com/newssummary.aspx?news=yes\&postid=16390.

14. Gabrielson, R. "U seeks tuition hike to help with budget cuts" in EastValleyTribune.com, Nov. 30, 2008. Available: http://www.eastvalleytribune.com/story/131519.

15. "California slightly below revenue projections" in The Sacramento Bee, Sept. 16, 2009. Available: http://www.sacbee.com/static/weblogs/capitolalertlatest/025525.html.

16. Mickalonis, E. A. "2010-2011 budget talks begin” in LegislativeGazette.com, Nov. 16, 2009. Available: $\quad$ http://www.legislativegazette.com/Articles-c-2009-11-16-63978.113122_2010_2011_ budget talks begin.html.

17. "Ohio's 2010-2011 Budget" in The Ohio Society of CPA, 2009. Available: http://www.ohioscpa.com/Content/45496.aspx.

18. Kelderman, E. "Calculating the true cost of tuition freezes at public colleges" in The Chronicle of Higher Education 55(36): A19, May 15, 2009. Available: http://chronicle.com/article/Calculatingthe-True-Cost-of/44341/.

19. National Conference for States Legislatures. "Spotlight: State budget update," 2009. Available: http://www.ncsl.org/?tabid=17498. 
20. Mactaggart, T. "The realities of rescuing colleges in distress" in The Chronicle of Higher Education 54(7): B11, Oct. 12, 2007. Available: http://chronicle.com/article/The-Realities-of-Rescuing/16705/.

21. Wash, M. "Muni bonds may face downgrade," in New York Times.com, Apr. 9, 2009. Available: http://www.nytimes.com/2009/04/08/business/economy/08muni.html.

22. Blumenstyk, G. "Debt bomb is ticking loudly on campuses" in The Chronicle of Higher Education 55(31): A1, Apr. 10, 2009. Available: http://chronicle.com/weekly/v55/i31/31a00101.htm.

23. Basken, P. and K. Field. "Sallie Mae tying loans to students' credit scores and colleges' graduation rates" in The Chronicle of Higher Education 54(21): A19, Feb. 1, 2008. Available: http://chronicle.com/weekly/v54/i21/21a01902.htm.

24. Wang, P. "Is college still worth the price" in CNNMoney.com, Apr. 13, 2009. Available: http://money.cnn.com/2008/08/20/pf/college/college_price.moneymag.

25. “Aid applications and direct loan volume are both U Inside Higher Education Quick Takes” in Inside Higher Education, March $2009 . \quad$ Available: http://www.insidehighered.com/layout/set/print/news/2009/03/09/qt.

26. Field, K. "Private-loan borrowing continues rapid growth, analysis shows" in The Chronicle of Higher Education, Apr. 21, 2009. Available: http://chronicle.com/news/article/6355/private-loanborrowing-continues-rapid-growth-analysis-shows.

27. "2008 national student postsecondary aid study (NSPAS) finds 66 percent of undergraduates received aid" in National Association of Student Financial Aid Administration, Apr. 15, 2009. Available: http://www.nasfaa.org/publications/2009/rnnpsas041509.html.

28. "StudentPoll: The effects of the current recession," College Board \& Arts \& Science Group 7(3): 2009. Available: http://www.artsci.com/studentpoll/v7-3/index.aspx.

29. Snyder, S. "Colleges unsure of enrollment picture" in Philadelphia Inquirer, Apr. 24, 2009. Available (for fee): http://www.philly.com/inquirer/home_region/20090424_Colleges_unsure_of_ enrollment_picture.html.

30. Wee, G. "Harvard Investments Lose 27.3\%, Less Than Forecast (Update1)" in Bloomberg.com, Sept. 10, 2009. Available: http://www.bloomberg.com/apps/news?pid=20601087\&sid=azaVNoupoSkA.

31. Debeneditti, G. "Endowment value drops 22.7 percent; layoffs expected" in Daily Princetonian, Sept. 30, 2009. Available: http://www.dailyprincetonian.com/2009/09/30/23943/.

32. Oxholm, C. "Sarbanes-Oxley in Higher Education: Bringing Corporate America's 'Best Practices' to Academia” in Journal of College and University Law, University of Notre Dame Law School 31(2): 2005.

33. Masterson, K. "Recession tempers the usual optimism in college fund-raising offices" in The Chronicle of Higher Education 55(8): A16, January 9, 2009. Available: http://chronicle.com/weekly /v55/i18/18a01601.htm.

34. Masterson, K. "Q and A: Making tough choices in the fund-raising office" in The Chronicle of Higher Education 55(36): A15, May 15, 2009. Available: http://chronicle.com/article/QA-MakingTough-Choices/44337.

35. Masterson, K. "With dwindling resources, colleges recalibrate fund-raising staffs" in The Chronicle of Higher Education 53(32): A20, April 17, 2009. Available: http://chronicle.com/article/WithDwindling-Resources-C/9283.

36. Carlson, S. "Campus officials seek building efficiencies, one square Foot at a time” in The Chronicle of Higher Education 55(32): A1, 2009.

37. Association of General Contractors of America. "Surging fuel, asphalt, steel costs 'clobber' construction budgets, AGC say" in ConstructionNews, July 15, 2008. Available: http://www.agc.org/cs/news_media/press_room/press_release?pressrelease.id=198.

38. Crowley, P. "As universities age, billions-worth of projects on table” in Business First of Columbus, 2008. Available: $\quad$ http://columbus.bizjournals.com/columbus/stories/2008/09/08 /focus1.html?b=1220846400\%5E1695637.

39. AAA Daily Fuel Gauge Report in American Automobile Association. 2009. Available: http://www.fuelgaugereport.com. 
Re-Examining \& Repositioning Higher Education: Twenty Economic and

Demographic Factors Driving Online and Blended Program Enrollments

40. Young, J. “\$4-a-gallon gas drives more students to online courses” in The Chronicle of Higher Education 54(45): A20, July 18, 2008. Available: http://chronicle.com/article/4-a-Gallon-GasDrives-More/16188.

41. Grasgreen, A. "Price of gas fuels tough choices for adjuncts" in The Chronicle of Higher Education 45(44): A1, July 11, 2008.

42. Feggins, S. "Fluctuating gas prices brakes students who commute" in The News Argus, Nov, 27, 2006. Available: http://media.www.thenewsargus.com/media/storage/paper646/news/2006/11/27 /CampusNews/Fluctuating.Gas.Prices.Brakes.Students.Who.Commute-2516044.shtml.

43. Sedov, M. "Gas prices taking toll on student drivers" in The Ticker. Baruch College, City University of New York, May 1, 2006. Available: http://media.www.theticker.org/media/storage /paper909/news/2006/05/01/News/High-Gas.Prices.Taking.Toll.On.Student.Drivers-1897754.shtml.

44. Kadden, J. “An expert's view of college costs” in New York Times, Nov. 19, 2009. Available: http://thechoice.blogs.nytimes.com/2009/11/19/costs.

45. "Most expensive college dorms for 2009-2010" in Campus Grotto, 2009. Available: http://www.campusgrotto.com/most-expensive-college-dorms-for-2009-2010.html.

46. Hermes, J. J. "Soaring food prices Squeeze Dining Halls" in The Chronicle of Higher Education 54(36): A20, May 16, 2008.

47. Foderaro, L. "Without cafeteria trays, colleges find saving” in New York Times.com, Apr. 28, 2009. Available: http://www.nytimes.com/2009/04/29/nyregion/29tray.html.

48. Jayson, S. "Getting the most bang for your college buck" in USA Today, 2009. Available: http://www.usatoday.com/money/perfi/college/2009-01-07-best-value-colleges_N.htm.

49. Allison, D. H., \& B. DeBlois. and the 2008 EDUCAUSE Current Issues Committee, “ Top ten IT issues" in EDUCAUSE Review 43(3): 36-61, May/June 2008. Available: http://www.ed.gov/about/bdscomm/list/hiedfuture/factsheet.pdf.

http://www.educause.edu/EDUCAUSE+Review/EDUCAUSEReviewMagazineVolume43/TopTenIT Issues2008/162885.

50. McClure, A. “Technology spending survey '08” in University Business, December 2007. Available: http://www.universitybusiness.com/viewarticle.aspx?articleid=960.

51. Spellings Commission on the Future of Higher Education. "Issue paper" 4: 2006. Retrieved from http://www.ed.gov/about/bdscomm/list/hiedfuture/factsheet.pdf.

52. Passel, J., \& D. Cohn. "Immigration to play lead role in future U.S. growth, U.S. population projections: 2005-2050” in Pew Research Center, Washington, DC, Feb. 11, 2008. Available: http://pewresearch.org/pubs/729/united-states-population-projections.

53. United States Census Bureau. “An older and more diverse nation by midcentury,” Washington, DC, Aug. 14, 2008. Available: http://www.census.gov/Press-Release/www/releases/archives /population/012496.html.

54. Walton, C. "College Tuition and Undocumented Immigrants," National Conference of State Legislatures. Legisbrief 11(39): 2, October 2003.

55. United States Census Bureau. "Florida, California and Texas to dominate future population growth,” Washington, DC, Apr. 21, 2005. Available: http://www.census.gov/PressRelease/www/releases/archives/population/004704.html.

56. Western Interstate Commission for Higher Education. Knocking at the College Door: Projections of High School Graduates by State and Race/Ethnicity, 1992 to 2022, Boulder, CO, 2008. Available: http://wiche.edu/knocking.

57. Ashburn, E. "New data predict major shifts in student population, requiring colleges to change strategies" in The Chronicle of Higher Education, March 20, 2008. Available: http://chronicle.com/article/New-Data-Predict-Major-Shifts/606.

58. Almanac. "Projected change in the number of high-school graduates, 2008-9 to 2018-19" in The Chronicle of Higher Education 55(14): 4, Aug. 29, 2008. Available: http://chronicle.texterity.com /chronicle/almanac200809/?pg=6.

59. Asimov, N. "More eligible students, fewer college slots” in San Francisco Chronicle, Dec.10, 2008. 
Re-Examining \& Repositioning Higher Education: Twenty Economic and

Demographic Factors Driving Online and Blended Program Enrollments

San Francisco, CA. Available: http://www.sfgate.com/cgi-bin/article.cgi?f=/c/a/2008/12/09 BA1314IG75.DTL.

60. Merrill Lynch. "The New Retirement Survey" from Merrill Lynch reveals how baby boomers will transform retirement, Washington, DC, 2005. Available: http://www.harrisinteractive.com/services /pubs/Merrill_Lynch_Baby_Boomers_Retirement.pdf.

61. American Council for Education (ACE). Framing New Terrain: Older Adults and Higher Education. Washington, DC, Oct. 2007.

62. “Craig McGuinn, Ward Media, Inc. Gazette Minute Interview” in GreenTree Gazette, Dec. 9, 2008. Available: http://www.greentreegazette.com/newsletters/newsletter_081209.html.

63. Obama, B. "Remarks by the President on higher education,” Diplomatic Reception Room, Apr. 9, 2009. Available: http://my.barackobama.com/page/community/post/obamaforamerica/gGxWJX.

64. Duncan, A. "United States Department of Education Secretary Duncan highlights budget proposals to increase college access and affordability," Washington, DC, February 26, 2009. Available: http://www.ed.gov/news/pressreleases/2009/02/02262009.html.

65. Cavanaugh, J. C. "Cost reductions and tuition restraint: Been there done that. Commentary” in The Chronicle of Higher Education 55(27): A34, March 13, 2009.

66. Usher, A. \& A. Cerveran. "Global higher education rankings: Affordability and accessibility in comparative perspective," Toronto, ON: Educational Policy Institute, 2005. Available: http://www.educationalpolicy.org/pdf/Global2005.pdf.

67. United States Census Bureau. "Census Bureau releases data showing relationship between education and earnings 2009." Available: http://www.census.gov/Press-Release/www/releases /archives/education/013618.html.

68. Baum, S. \& J. Ma. Education pays: The benefits of higher education for individuals and society, College Board. Washington, DC, 2007. Available: http://www.collegeboard.com /prod_downloads/about/news_info/cbsenior/yr2007/ed-pays-2007.pdf.

69. Holzer, H. "Economic cost of inadequate investments in workforce development" in Testimony Submitted to Subcommittee on Labor and Human Services, Education and Related Agencies, US House of Representatives, Feb. 26, 2008. Available: http://www.urban.org/UploadedPDF 1901149_Holzer_workforce.pdf.

70. United States Department of Labor. Career Voyage, Sept. 19, 2007. Available: http://www.careervoyages.gov/.

71. Newsweek. "Distance learning and online degrees" in Newsweekshowcase.com, Apr. 1, 2009. Available: $\quad$ http://www.newsweekshowcase.com/education/distance-learning/articles/distancelearning-allabout.

72. "Multi-billion dollar industries: Part III" in SmartCompany.com. June 19, 2008. Available: http://www.smartcompany.com.au/information-technology/multi-billion-dollar-industries-partiii.html.

73. "Study: E-Learning Spending on the Rise” in MediaTech Publishing, 2007. Available: http://www.clomedia.com/talent.php?pt=a\&aid=1916.

74. United States Distance Learning Association launches National Distance Learning Week to increase the awareness of distance learning, Drexel University, Sept. 19, 2007. Available: http://www.drexel.edu/news/headlines/usdla-launches-national-distance-learning-week-to-increasethe-awareness-of-distance-learning.aspx.

75. Young, J. "Minnesota state colleges plan to offer one-fourth of credits online by 2015" in The Chronicle of Higher Education, Nov. 20, 2008. Available: http://chronicle.com/wiredcampus /article/3476/minnesota-state-colleges-plan-to-offer-one-fourth-of-credits-online-by-2015.

76. Belcher, K. "DANTES' $35^{\text {th }}$ Birthday” in Military Advanced Education, Journal of Higher Learning for Today’s Servicemember 4(5): September/October 2009. Available: http://www.military-advancededucation.com/mae-archives/188-mae-2009-volume-4-issue-4/1776-dantes-35th-birthday.html.

77. "Education Benefits," United States Department of Veterans Affairs, 2009. Available: http://www.gibill.va.gov/GI Bill Info/benefits.htm. 
Re-Examining \& Repositioning Higher Education: Twenty Economic and Demographic Factors Driving Online and Blended Program Enrollments

78. Hendry, E. "Cost of colleges' health-care benefits continues to rise” in The Chronicle of Higher Education, July 28, 2008. Available: http://chronicle.com/article/Cost-of-Colleges-Health-Ca/47482. 